\title{
O TRABALHO DO SONHO NA POÉTICA SURREALISTA
}

\section{PAULA CARPINETTI AVERSA}

Paula Carpinetti Aversa

Universidade Estadual Paulista "Júlio de Mesquita Filho" (UNESP). Doutoranda no Instituto de Psicologia, Programa de Pós-Graduação em Psicologia, Assis/SP, Brasil.
RESUMO: O artigo procura tecer as contribuições freudianas na construção da poética surrealista. Os artistas deste movimento artístico, declaradamente, fizeram uso ativo das explorações do inconsciente. Assim, pretende-se explicitar que, para além das imagens oníricas que traziam os temas psicanalíticos (como o Édipo, a sexualidade, a histeria), os surrealistas procuravam explorar o próprio "trabalho do sonho" como procedimento artístico para a construção de suas imagens artísticas.

Palavras-chave: sonho; artes; surrealismo.

Abstract: The work of the dream in the surrealist poetics. The article tries to weave as Freudian contributions in the construction of surrealist poetics. The artists of this artistic movement, reportedly, use the exploits of the unconscious. Thus, it is intended to make explicit that, in addition to the dreamlike images that psychoanalytical themes (such as Oedipus, a sexuality, a hysteria) brought, the surrealists sought to explore their own "dream work" as an artistic procedure for constructing their images artistic activities.

Keywords: dream; art; surrealism.

DOI - http://dx.doi.org/10.1590/1809-44142018001012 
Este artigo pretende tecer algumas considerações sobre as contribuições freudianas para o universo das artes visuais, mais especificamente para a poética surrealista, a partir da apropriação que os artistas deste movimento artístico fizeram das explorações freudianas do sonho.

São inúmeros os estudos que explicitam as ressonâncias entre as elaborações psicanalíticas e artísticas da modernidade. Contudo, é também sabido que o próprio Freud não aprovava a arte moderna. 0 expressionismo, por exemplo, não escapou às duras críticas de Freud, como podemos verificar em uma das cartas que este escreve a Oskar Pfister, datada de junho de 1920:

Querido Doutor,

Peguei em mãos seu pequeno livro sobre o expressionismo tanto com interesse como com aversão, e li de um fôlego só (...). Quero que saiba que sou terrivelmente intolerante em relação aos loucos, nos quais vejo apenas os lados nocivos; no que se refere a estes 'artistas', sou realmente um daqueles que o senhor condena no início de seu livro, qualificando-os de filisteus e pedantes. (FREUD apud GOMBRICH, 1995, p. 9)

Em outra carta, desta vez destinada a Karl Abraham, Freud é ainda mais cáustico:

Caro amigo,

Recebi o desenho que supostamente representa sua cabeça. É horrível. Sei o homem notável que é você, e estou mais transtornado ainda pelo fato de que mancha tão leve no seu retrato moral - sua tolerância ou simpatia pela 'arte' moderna - deva ser tão cruelmente castigada. Soube através de Lampl que o artista declarou que é assim que o vê! Pessoas como ele deveriam, menos que os outros, ter acesso aos meios psicanalíticos, pois ilustram de modo por demais indesejável a teoria de Adler segundo a qual são justamente as pessoas atingidas por um grave defeito congenital da visão que se tornam artistas. (idem)

Em compensação, muitos artistas modernos (sobretudo os surrealistas), fizeram referências evidentes às formulações freudianas, principalmente em relação à obra Interpretação dos sonhos, que tem o ano de 1900 como data de primeira edição, a despeito das opiniões do psicanalista vienense que teria um dia afirmado: “Nas pinturas clássicas procuro o inconsciente - em uma pintura surrealista, o consciente" (RIVERA, 2002, p. 22), deixando claras as suas reservas em relação às vanguardas que, em seu parecer, não se dignavam a serem chamadas de arte. Para Freud: uma "superabundância de matéria inconsciente, somada a uma fraca elaboração pré-consciente, não resulta numa obra de arte” (GOMBRICH, 1995, p. 10).

Tal como podemos acompanhar nos estudos de Roudinesco (2003), a entrada e o fortalecimento do movimento psicanalítico na França deveram-se em grande parte ao surrealismo, que tinha como participantes ativos um "clube de doutores", bastante familiarizados com as elaborações freudianas, que contribuíram enormemente para a divulgação do campo psicanalítico. Henri Ey, psicanalista da chamada segunda geração, afirmou que "foi através do surrealismo, e não da literatura médica, que descobriu a importância do freudismo" (ROUDINESCO, 2003 [V.II], p.25).

Em 1921, o jovem Breton faz uma visita ao mestre em Viena. Freud o recebe entre suas sessões de análise vespertinas e parece ao poeta um senhor pequeno-burguês sem ares de importância. Não demonstrando nenhum interesse pelo movimento dadaísta ao qual Breton está então ligado, Freud afirma laconicamente que é bom poder contar com os jovens. Colecionador de antiguidades, Freud era um homem de grande erudição e gosto austero, que apreciava enormemente obras clássicas e nunca se aproximou das vanguardas artísticas e literárias de Viena de sua época. Ele não percebe o papel que Breton e seus companheiros terão na divulgação da psicanálise na França, onde as resistências do meio médico e uma germanofobia disseminada levantavam barreiras à entrada do freudismo. (RIVERA, 2002, p. 9)

Logo nos primeiros anos do século XX, em plena Primeira Guerra Mundial, nasceu o movimento dadaísta: uma reação artística radical de desgosto frente à mentalidade burguesa. $O$ dadaísmo nasceu "de um desejo implacável de atingir uma moral absoluta, do sentimento profundo de que o homem, no centro de todas as criações do espírito, tivesse de afirmar a sua proeminência sobre as noções empobrecidas da substância 
humana, sobre as coisas mortas e sobre os bens mal adquiridos (....), uma revolta que exigia uma adesão completa do indivíduo às necessidades da sua natureza, sem nenhuma consideração com a história, a lógica, a moral comum (...)" (MICHELI, 2004, p. 132).

O Manifesto Dadaísta, datado de 1918, nos esclarece sobre as intenções do movimento:

Os que estão conosco conservam a sua liberdade. Nós não reconhecemos nenhuma teoria. Basta com as academias cubistas e futuristas, laboratório de ideias formais. A arte serve então para amontoar dinheiro e acariciar os gentis burgueses? (...) Todos os grupos de artistas acabaram neste banco, mesmo cavalgando cometas diferentes (...). Transbordamos de maldições sobre a abundância tropical e de vegetação vertiginosas (...). Eu sou contra os sistemas. O único sistema ainda aceitável é o de não ter sistemas. A lógica é sempre falsa. A moral atrofia (...). Todo homem deve gritar. Há um grande trabalho destrutivo, negativo, a ser executado. (TZARA apud MICHELI, 2004, p. 136)

Os artistas dadás não procuravam uma uniformalização estilística ou organizadora; mas, sobretudo, o significado polêmico do procedimento. Nesta poética, o que impera é o gesto de polemizar, negar e destruir a lógica: "Muitas 'obras' dadaístas foram 'fabricadas' com o método da 'poesia no chapéu', ou seja, recolhendo os elementos mais disparatados e colocando-os todos juntos" (MICHELI, 2004, p. 138).

O procedimento artístico da colagem faz parte da negação dadaísta. Produto do acaso e do improviso, a colagem estabelece conexões inusitadas e enigmáticas, fora da lógica. Segundo Max Ernst, "a técnica da colagem é a exploração sistemática do encontro casual ou artificialmente provocado de duas ou mais realidades estranhas entre si sobre o plano aparentemente inadequado e um cintilar de poesia que resulta da aproximação dessas realidades" (ERNST apud PASSETTI, 2007, p. 5).

Para produzir os seus Merz, o artista Kurt Schwitters utilizava-se de tudo o que encontrava: pedaços de madeira e de ferro, penas de galinha, passagens de bonde, envelopes, selos, pedras, solas de sapato, panos, palavras recortadas de jornais etc. Todo tipo de objetos ou detritos do cotidiano eram recuperados e dispostos de maneira aleatória. Em Nova York, na mesma época, as produções dadaístas de Duchamp - que, por exemplo, propunha seus Rendez vous d'art (Encontros de arte), determinando arbitrariamente que, numa certa hora do dia, o primeiro objeto que estivesse ao alcance seria designado como um ready-made -, a "arte amorfa" (que não representa nada e que não é nada) de Picabia e as inventivas técnicas fotográficas de Man Ray completavam o panorama dadaísta que ultrajavam e buscavam destruir as normas morais e estilísticas vigentes.

Na medida em que Duchamp expunha como obra de arte um objeto obviamente não artístico, punha em evidência provocativamente o caráter supérfluo da arte. Certamente, o protesto dadaísta contra a arte partia da legítima exigência de sua aproximação aos problemas da vida ou, mais exatamente, de sua participação nas tarefas de renovação da cultura e da sociedade (...). Ao mesmo tempo em que Duchamp declarava a obra de arte como objeto não-artístico, elevava o produto técnico à obra de arte definitiva. De um lado, afirmava-se que tudo pode ser arte e, por conseguinte, que a arte não é nada; de outro, reivindicava-se o objeto mecânico como verdadeira forma artística. Tudo isso foi seriamente considerado como a superação dos limites históricos, ou melhor, dos limites burgueses de um esteticismo vazio. (SUBIRATS, 1984, p. 80)

Hans Richter rasgava desenhos e deixava que os fragmentos caíssem ao acaso, formando outra imagem em que não interviria. O poeta e artista plástico Arp, que, por sua vez, realizava desenhos espontâneos com o livre fluir de tintas, também "rasgava" frases, pinçando palavras ou expressões de um jornal: "Maravilha mundial envia cartão imediatamente aqui é uma parte de um porco todas as 12 partes reunidas fixaram-se o apartamento dará uma clara vista lateral de um estêncil surpreendentemente barato todos compram" (ARP [1917] apud ADES, 2000, p. 181). Para Hans Arp, o dadaísmo visava “(...) destruir as razoáveis ilusões do homem e recuperar a ordem natural e absurda. (...) Dadá é a favor do não sentido, o que não significa contrassenso. Dadá é desprovido de sentido como a natureza. Dadá é pela natureza e contra a arte. Dadá é direto como a natureza" (ARP apud ADES, 2000, p. 181). 
Caracterizando-se, desta forma, como uma anti-arte, era lógico que dadá matasse o dadaísmo. Já nos primeiros anos da década de 1920, o dadaísmo se encerra como movimento e muitos de seus artistas aderem ao surrealismo como o próprio André Breton e Marx Ernst.

Vários procedimentos dadaístas continuaram a ser exercitados no movimento surrealista: a questão da liberdade expressiva, as relações inusitadas de elementos compositivos, as atitudes destrutivas, os gestos provocativos, o sentimento de revolta frente aos valores burgueses. O lema dos surrealistas - frase de Lautréamont - revela claramente a influência dadá: "Tão belo como o encontro fortuito, em uma mesa onde se pratica a dissecação, de uma máquina de costura com um guarda-chuva" (LAUTRÉAMONT apud DEMPSEY, 2003, p. 151).

Porém, o surrealismo foi um movimento extremamente organizado com teorias doutrinárias. Neste sentido, diferente da poética dadá; enquanto este último fundamentava-se na negação e na destruição, o surrealismo afirmava-se pela construção, substituindo a rejeição total pela pesquisa experimental, construindo um sistema de conhecimento. André Breton, idealizador do movimento, partia das concepções do marxismo, de filosofias ocultistas e, como já foi apontado anteriormente, da psicanálise para estruturar o surrealismo. Em seu Primeiro Manifesto, de 1924, Breton define o movimento: "pensamento que é expresso na ausência de qualquer controle exercido pela razão e alheio a todas considerações morais e estéticas" (BRETON apud NADEAU, 2008, p. 55). Vale reproduzir um trecho mais amplo desta definição:

Surrealismo. s.m. Automatismo psíquico puro pelo qual se exprime, quer verbalmente, quer por escrito, quer de outra maneira, o funcionamento real do pensamento. Ditado do pensamento, na ausência de qualquer controle exercido pela razão, fora do âmbito de qualquer preocupação estética ou moral.

Encicl. Filos. O surrealismo repousa sobre a crença na realidade superior de certas formas de associações negligenciadas até então, na onipotência do sonho, no jogo desinteressado do pensamento. Tende a arruinar definitivamente todos os outros mecanismos psíquicos e a substituí-los na solução dos principais problemas da vida (...). (BRETON apud NAUDEAU, 2008, p. 55)

Enfatizando o automatismo psíquico, Breton (também médico, bastante familiarizado com os conceitos freudianos) afirmava que tanto a poesia, a prosa ou a pintura deveriam originar-se do encadeamento das primeiras palavras ou imagens que ocorressem à mente.

Foi em 1919 que minha atenção se fixou nas frases mais ou menos parciais que, em plena solidão, à chegada do sono, se tornam perceptíveis ao espírito sem que possa descobrir-lhes (a não ser com uma análise bastante minuciosa) uma determinação prévia. Certa noite em especial, antes de adormecer, percebi nitidamente articulada, a ponto de ser impossível mudar-lhe uma palavra sequer, mas isolada, no entanto, de qualquer ruído vocal, uma frase bastante bizarra que me chegava sem trazer vestígio dos acontecimentos aos quais, conforme o testemunho de minha consciência, eu me encontrava misturado naquele momento, frase que me pareceu insistente, frase, ousaria dizê-lo, que martelava a vidraça. Rapidamente tomei consciência dela e me dispunha a passar além quando seu caráter orgânico me deteve. Na verdade essa frase me espantava; infelizmente não a guardei até hoje, era alguma coisa como: 'Há um homem cortado em dois pela janela', mas ela não podia sofrer equívoco, acompanhada que estava da fraca representação visual de um homem andando e cortado ao meio por uma janela perpendicular ao eixo do corpo. Fora de qualquer dúvida, tratava-se de simples reerguimento no espaço de um homem que se mantinha debruçado à janela. Mas como tal janela havia seguido o deslocamento do homem, eu percebia que estava diante de uma imagem de tipo raro que tive desejo de incorporá-la a meu material de construção poética (...). Totalmente ocupado com Freud, como ainda estava naquela época, e familiarizado com os métodos de exame que tivera alguma oportunidade de praticar com pacientes de que tratara durante a guerra, resolvi ir buscar em mim mesmo aquilo que tentávamos obter neles, ou seja, um monólogo falado o mais rápido possível, sobre o qual o espírito crítico do sujeito não faça qualquer juízo, que não se embarace em seguida com qualquer reticência, e que seja tão exatamente quanto possível o pensamento falado. (BRETON apud NADEAU, 2008, p. 47-48)

Do ponto de vista dos procedimentos artísticos, os surrealistas apropriaram-se da desinibição dadaísta, bem como ainda se valiam de técnicas tradicionais (como a pintura). Além de retirar um objeto de seu 
contexto original e lançá-lo para outros contextos e relações inusitadas, atribuindo a ele a condição de obra de arte, prática executada deste os dadaístas e mesmo a elaboração dos chamados "objetos surrealistas" - como o ferro de passar cheio de pregos ou a xícara de chá forrada de pele -, os surrealistas incorporam o objet trouvé nos seus processos criativos: Juan Miró, todas as manhãs, ia para a praia e colhia as diversas coisas trazidas pela maré. "O objet trouvé, francês para 'objeto encontrado', acompanha o princípio do ready-made: objeto qualquer encontrado pelo artista e transformado em obra de arte. Mas enquanto o ready-made é um objeto entre vários iguais a ele, o objet trouvé é escolhido em função de sua singularidade" (LODDI, 2010, p. 30). Max Ernst entendia a frottage - procedimento que consiste na friç̧ão de um lápis (ou outro instrumento semelhante) num papel apoiado por sob uma superfície para registrar sua textura - o equivalente plástico da escrita automática, por extrapolar o controle e evitar questões de gosto ou habilidade. $\mathrm{O}$ automatismo, regido pelo inconsciente, aparecia como "o principal caminho de acesso ao maravilhoso" (BRADLEY, 1999, p. 21), sendo considerado como o método surrealista por excelência.

Segredos da arte mágica surrealista. Composição surrealista escrita, ou primeiro e último esboço: pensem que vão escrever depois de se haverem estabelecido num lugar, o mais cômodo possível, para que o espírito possa concentrar-se sobre si mesmo. Sejam extremamente passivos ou o mais receptivos que puderem (...). Escrevam rápido sem assunto prefixado, bastante depressa para nada guardar na memória e para não serem tentados a reler o que escrevem. A primeira frase fluirá naturalmente (...). É muito difícil pronunciar-se sobre o caso da frase seguinte (...). Pouco lhes importa, aliás. (BRETON apud NADEAU, 2008, p. 56)

Desta maneira, os procedimentos surrealistas aproximavam-se das elaborações oníricas. Mais do que utilizar os temas psicanalíticos, como o Édipo, a sexualidade e a histeria (explorados em inúmeras imagens artísticas, inclusive, de outros movimentos artísticos), os surrealistas compreendiam o sentido poético dos mecanismos mesmos do trabalho do sonho que Freud elucidou. Em outras palavras: o trabalho do sonho era tomado como o modus operandi dos procedimentos artísticos surrealistas.

Em A interpretação dos sonhos (1900), Freud revela as leis e as características do inconsciente, enfatizando que o sonho é a realização de um desejo, isto é, as produções oníricas procuram reencontrar uma satisfação perdida remetida às primeiras experiências da infância. São estas reminiscências infantis evocadas pelas experiências recentes que constituem o onírico, após serem deformadas pelo trabalho do sonho.

Freud estava particularmente interessado nos sonhos porque supunha que os mesmos mecanismos existentes neles também estavam presentes nas formações dos sintomas neuróticos, considerando o sonho como a via régia para o inconsciente. Assim como nos sintomas, o desejo inconsciente realiza-se disfarçadamente nos sonhos, burlando a censura consciente. Segundo Marthe Robert (1991):

(...) Freud descobriu o significado dos sonhos ao procurar investigar o porquê e o como das neuroses. É certo que as duas ordens de investigações desde cedo apareceram tão intimamente ligadas que forçosamente tinham de reciprocamente se influenciar: as neuroses tinham-Ihe revelado a importância do sonho, o sonho por seu lado deu-lhe a chave das neuroses. (ROBERT, 1991, p. 99)

Para que seja possível sonhar, ou seja, para que o desejo possa realizar-se disfarçadamente, a partir de um curso regressivo em relação aos estados de vigília, há o trabalho do sonho que faz uso basicamente dos seguintes mecanismos: a figuração, a condensação, o deslocamento, a inversão e elaboração secundária; alguns mecanismos estes, deliberadamente, buscados na execução das produções surrealistas. Tal como Garcia-Roza (2002) nos esclarece, o termo trabalho deve ser tomado "no seu sentido forte, isto é, como designando o processo pelo qual uma matéria-prima é transformada em seu produto" (GARCIA-ROZA, 2002, p. 82).

A noção de regressão - concebida a partir do estudo dos sonhos - encontra-se, portanto, no cerne do modelo de aparelho psíquico concebido por Freud. A elaboração onírica implica uma regressão no modo de funcionamento psíquico: os pensamentos latentes sofrem uma elaboração diversa do pensamento de vigília, 
que por meio de condensações, deslocamentos e da exigência de figurabilidade condiciona o aspecto "formal" do sonho, transformando o pensamento verbal em uma linguagem imagética, potencialmente metafórica - 0 processo primário. O sonho pensa por imagens. (GANHITO, 2001, p. 28-29)

Para Freud, o caráter visual do sonho - amplamente explorado pelos surrealistas - está relacionado à afinidade com o material recalcado, ou seja, com os registros mnêmicos das primeiras experiências de satisfação - "grupos de lembranças, especialmente as que existem apenas sob a forma de catexias visuais, sem tradução nos sistemas posteriores" (GANHITO, 2001, p. 25) - que são reativadas no sonho, em função da diminuição da censura.

Referindo ainda à sua primeira tópica, Freud explica os mecanismos do sonho fazendo uso do "modelo do pente": no qual os "dentes" seriam a sucessão linear das várias marcas ou registros psíquicos, do pólo perceptivo (órgãos do sentido), passando pelos traços mnêmicos inconscientes (que selecionam e modificam a percepção) até o pólo motor (sistema pré-consciente/consciente), este último relacionado à vigília, ao agir no mundo. Ao adormecer, há a inativação do pólo motor, diminuindo a censura, possibilitando que os desejos inconscientes sejam animados, favorecendo a satisfação pelo processo primário. Porém, a realização dos desejos inconscientes não pode ser evidente ou explícita, caso contrário, o sonhador acordaria; é necessário todo o trabalho do sonho para deformar os elementos recalcados, valendo-se de outros elementos menos investidos (ou catexizados) e, portanto, mais próximos da consciência, com a finalidade de que esses desejos inconscientes possam se satisfazer minimamente. É neste sentido que Freud entende o sonho como o "guardião do sono". Além de o sonho ser concebido como uma tela de projeção das imagens recalcadas (simbolizáveis pelo trabalho do sonho), satisfazendo os desejos inconscientes, o sonho é tela (ou anteparo) de proteção para o sono, garantindo a experiência íntima de regeneração do si mesmo, de restituição do narcisismo primário (quando os investimentos libidinais voltam-se ao eu, ou antes, quando o aparelho psíquico estava se constituindo e, portanto, não haveria ainda uma instância egóica propriamente, modelo da vida intra-uterina).

(...) o homem a cada noite se despoja dos envelopes com os quais recobre sua pele e também dos acessórios que eventualmente ele utiliza para complementar seus órgãos corporais, na medida em que podem camuflar sua deficiência por um substituto: óculos, perucas, dentaduras etc. Podemos acrescentar que ao ir deitar-se ele despe, de modo análogo, seu psiquismo, renunciando à maior parte de suas aquisições psíquicas, de modo que, dos dois lados, ele se aproxima ao extremo da situação que foi o ponto de partida de seu desenvolvimento (FREUD apud GANHITO, 2001, p. 37, grifos no original)

Assim, o dormir é uma retração da libido ao estado narcísico, para um tempo mítico de fusão do bebê com a mãe. É a retirada do interesse pelo mundo externo, abandonando a maioria das aquisições psíquicas (modelo uterino do sonho) e também a possibilidade da satisfação alucinatória do desejo inconsciente (modelo do sonho como realização do desejo).

O mecanismo da figuração (ou consideração à representabilidade), do qual o trabalho do sonho se utiliza para tornar possível a satisfação alucinatória do desejo, diz respeito ao fato de que, nos sonhos, as imagens estão no lugar das palavras; enfatizando, novamente, que a imagem é o principal veículo de expressão do sonho. Para Freud, a figuração é responsável pelo desaparecimento das ligações entre os pensamentos latentes, substituindo-os por formas que podem indicar simultaneidade ou sucessão. Diferente da linguagem verbal, que necessita de uma estrutura codificada e relativamente rígida para que possamos compreendê-la, a linguagem visual (que tem outra sintaxe) permite, por exemplo, que se apresentem muitos elementos ao mesmo tempo, possibilitando serem "lidos" ou "apreendidos" ao mesmo tempo (de maneira simultânea, sem hierarquia ou ordem), assim como também permite sugerir uma sucessão de acontecimentos no tempo, recurso, por excelência, das imagens cinematográficas (série de fotogramas apresentados sucessivamente num curtíssimo intervalo) dando a sensação de movimento, deslocamento ao longo do tempo. 
A condensação permite que um conteúdo manifesto agregue ou combine vários elementos, "abreviando" os pensamentos latentes ou desejos recalcados. Através do Sonho da monografia de botânica (1996 [1900]), Freud explica este mecanismo:

(...) não só a ideia composta, "monografia de botânica", como também cada um de seus componentes, "botânica" e "monografia", separadamente, levaram por numerosas vias de ligação a um ponto cada vez mais profundo no emaranhado dos pensamentos do sonho. "Botânica" estava relacionada com a figura do Professor Gärtner [Jardineiro], com a aparência florescente de sua mulher, com minha paciente Flora e com a senhora [Sra. L.] sobre quem eu contara a história das flores esquecidas. Gärtner, por sua vez, levou ao laboratório a minha conversa com Königstein. Minhas duas pacientes [Flora e Sra. L.] tinham sido mencionadas no decorrer dessa conversa. Uma cadeia de ideias ligou a senhora das flores às flores favoritas de minha mulher, e daí ao título da monografia que eu vira por um momento durante o dia. Além desses, "botânica" fez lembrar um episódio em minha escola secundária e um exame da época em que eu estava na Universidade. A um novo tópico abordado em minha conversa com o Dr. Königstein - meus passatempos favoritos - veio juntar-se, por meio do elo intermediário do que eu, na brincadeira, chamava de minha flor favorita, a alcachofra, uma cadeia de ideias proveniente das flores esquecidas. Por trás das "alcachofras" estavam, de um lado, meus pensamentos sobre a Itália e, de outro, uma cena de minha infância que fora o início do que depois vieram a ser minhas relações íntimas com os livros. Assim, "botânica" era um ponto nodal sistemático no sonho. (FREUD, 1996 [1900], p. 308-309)

Nesta passagem, evidencia-se o quanto o elemento "botânica" carregava consigo, ou melhor, condensava, muitos outros elementos. Tal como Garcia-Roza (2011, p. 67) nos esclarece, a condensação "diz respeito ao fato de o conteúdo manifesto do sonho ser menor do que o conteúdo latente. $O$ inverso nunca se dá; jamais o conteúdo manifesto pode ser maior do que o latente". A condensação pode omitir determinados elementos do conteúdo latente, permitir que apenas um fragmento do latente se manifeste no sonho, ou, ainda, combinar diversos elementos latentes que possuem algo em comum por um único elemento do sonho.

Já o deslocamento, por sua vez, consiste na possibilidade que as ideias ou imagens têm, no inconsciente, de "emprestar" seu valor para outras ideias (ou imagens), de modo que fatos ou imagens aparentemente sem importância podem estar associados e estejam a serviço de encobrir estes desejos, compondo o material do sonho. Através deste mecanismo, determinado elemento ou ideia latente pode "pegar carona" em outro elemento menos investido (mais próximo da consciência e que, desta forma, possa "enganar" a censura) do aparato psíquico. Assim, o deslocamento permite que haja a transferência de intensidade pulsional para elementos de baixo valor psíquico. A consequência disso é que o conteúdo do sonho não mais se assemelha aos pensamentos latentes. Para exemplificar este mecanismo, Freud (1996 [1900], p. 209) faz uso da seguinte anedota: "Numa aldeia havia um ferreiro que cometera um crime capital. $O$ júri decidiu que o crime devia ser punido; porém, como o ferreiro era o único na aldeia e era indispensável, e como, por outro lado, lá havia três alfaiates, um destes foi enforcado em seu lugar".

A inversão é também um importante recurso do trabalho do sonho e consiste na transformação de um elemento latente em seu contrário. No caso Dora (FREUD, 1996 [1905]), no qual a análise de seus sonhos foi fundamental, temos exemplos deste mecanismo: o líquido da enurese e da masturbação torna-se seu contrário, no fogo que toma conta da casa; o seu amado pai é representado pelo odiado Sr. K, e assim sucessivamente.

Freud denomina de elaboração secundária a modificação do sonho com a finalidade de torná-lo mais coerente e compreensível, perdendo seu caráter, por vezes, absurdo. O autor não considera este quarto fator do trabalho do sonho exterior a ele: "A elaboração secundária é uma espécie de interpretação anterior à interpretação que empreendemos após o despertar e que, enquanto parte do trabalho do sonho, tem um efeito de distorção dos pensamentos latentes tanto quanto o operado pelos demais mecanismos do trabalho do sonho" (GARCIA-ROZA, 2002, p. 107). Dos mecanismos de elaboração onírica, este último, certamente, não era de muita serventia aos surrealistas, pois justamente procura construir uma lógica para o sonho, o que não estava muito longe das intenções desse grupo de artistas. 


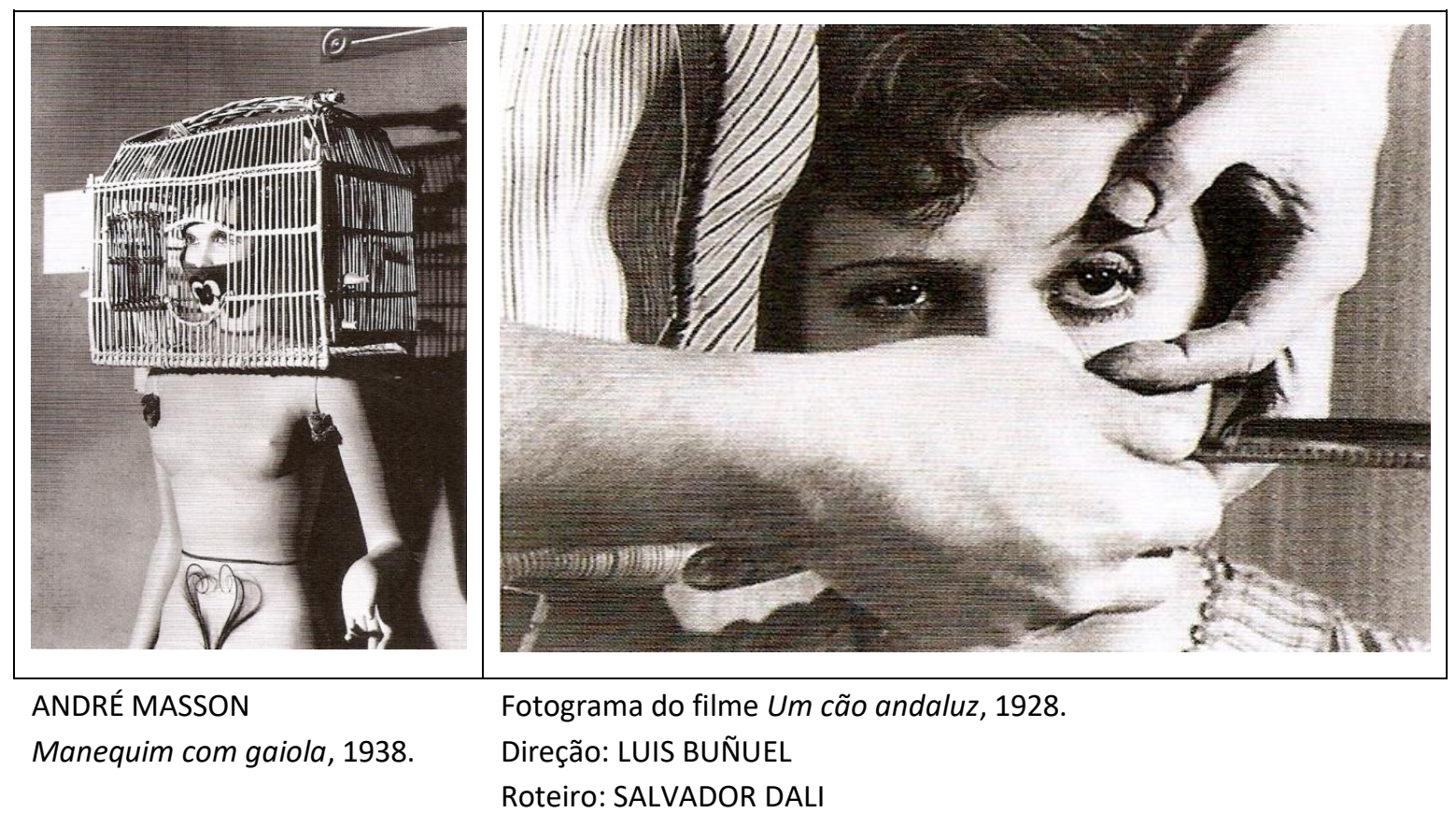

Estes mecanismos operam a partir da sobredeterminação, isto é, a partir do caráter múltiplo/plural das formações inconscientes (disto decorre também a superinterpretação: possibilidade de várias interpretações de um mesmo elemento ou do sonho como um todo). Nas próprias palavras de Freud: “(...) os elementos do sonho [conteúdo manifesto] são construídos a partir de toda a massa de pensamentos do sonho [conteúdos latentes] e cada um desses elementos mostra ter sido multiplamente determinado em relação aos pensamentos do sonho" (FREUD, 1996 [1900], p. 310). Ou ainda, como Freud coloca mais adiante em seu texto: “Portanto, parece plausível supor que, no trabalho do sonho, está em ação uma força psíquica que, por um lado, despoja os elementos com alto valor psíquico de sua intensidade, e, por outro, por meio da sobredeterminação cria, a partir de elementos de baixo valor psíquico, novos valores, que depois penetram no conteúdo do sonho" (ibidem, p. 333).

A interpretação - processo inverso ao trabalho do sonho, na medida em que, por meio da associação livre, procura rastrear os pensamentos latentes a partir do manifesto - é a técnica central do método psicanalítico e tem como objetivo buscar o desejo inconsciente a partir dos elementos manifestos (que não se restringem ao sonho, mas também aos atos falhos, sintomas etc.). $O$ que se pretende ressaltar é que 0 processo interpretativo do sonho (apesar de rico e revelador) não era exatamente o que interessava aos surrealistas. Estes não procuravam dar um sentido a suas obras, mas expor - pura e simplesmente - o material inconsciente por si, importando mais o aspecto regressivo do trabalho do sonho do que o progressivo do trabalho de interpretação. Nesta medida, interpretar os sonhos significava destruir a vivacidade do sonho.

Como já apontado, os surrealistas buscavam atingir um estado de entorpecimento semelhante aos estados regressivos do sono, isto é, buscavam fazer uso deliberado dos mecanismos da figuração, da condensação, do deslocamento, da inversão e da sobredeterminação para produzir suas obras. A procura ativa pelo desconhecido revela o desejo incomparável que estes artistas tinham de liberar seus espíritos, de se libertar de suas amarras egóicas. 


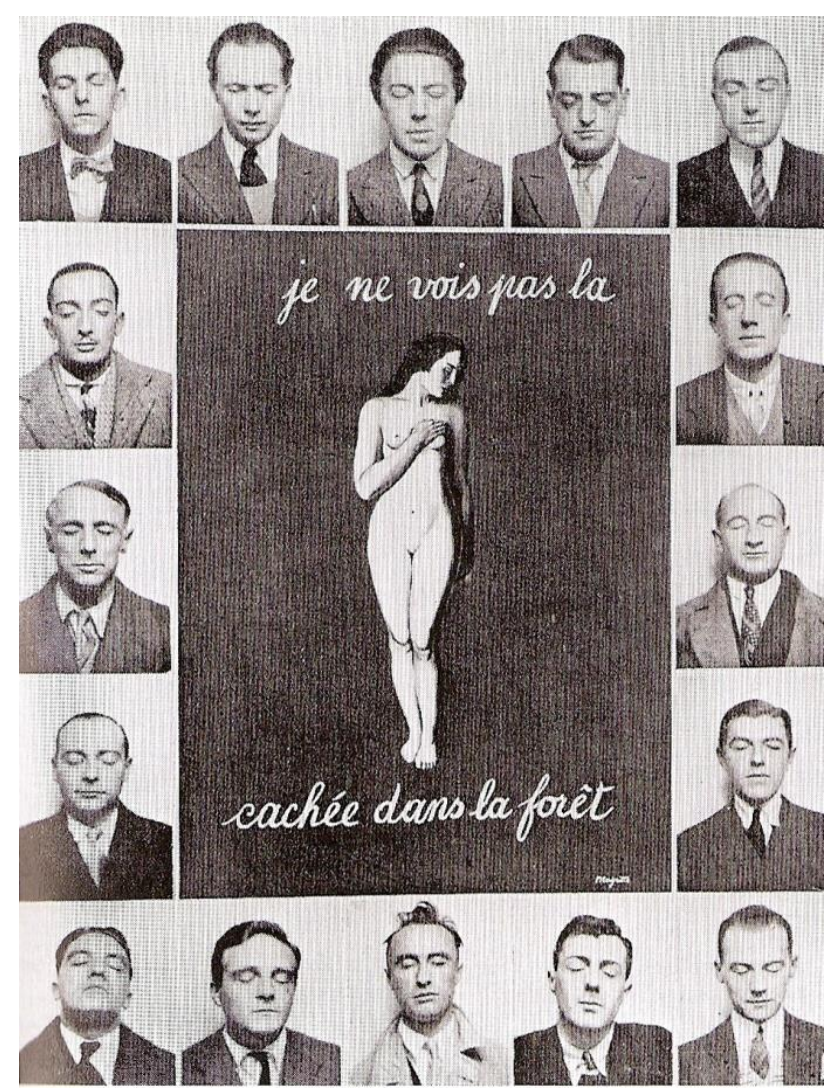

RENÉ MAGRITTE

A mulher escondida, 1929.

Para liberar as "forças" inconscientes, estes artistas se valiam de vários recursos, tais como aquilo que ficou conhecido como o "jogo do cadáver delicado" (ou "jogo das consequências"), no qual, a partir de um rabisco ou palavra, cada participante contribuía com um acréscimo ao trabalho, que ia passando de mão em mão. Ou, ainda, de outros recursos bastante polêmicos, como técnicas paranormais, transes e sono hipnótico:

Uma noite, em setembro de 1922, por iniciativa de René Crevel, alguns amigos decidem dormir no estúdio de rua Fontanie, para onde Breton acaba de se mudar. $\mathrm{O}$ aparato exterior do espiritismo é logo empregado: os convidados dispõem-se em círculo ao redor de uma mesa, com os dedos afastados sem rigidez. Crevel bate com a cabeça na madeira da mesa e se lança numa improvisação falada. Muito depressa, Desnos se revela um adormecido fabuloso: monologa, escreve, desenha e depois se presta a toda sorte de diálogos. Seus companheiros o interrogam sobre o futuro do mundo (...). Um ano depois, Breton resolve pôr fim à dupla experiência do sono hipnótico e da escrita automática. Apercebe-se de que ele próprio está sujeito a alucinações e de que alguns de seus amigos estão tendo perturbações. Uma noite, depois de uma sessão de mesas giratórias, várias pessoas adormecidas tentam pendurar-se em cabides: a ideia parte de Crevel. Numa outra noite, depois de um jantar, Desnos, em estado sonambúlico, persegue Éluard no jardim e quase o mata com uma faca. Como psiquiatra esclarecido, Breton se dá conta de que a experiência está se tornando perigosa. Deixa então a escrita automática, um pouco à maneira como Freud havia abandonado a hipnose. Entretanto, em 1924, em sua definição do surrealismo, conserva a ideia de um ditame, fora de qualquer controle da razão. (ROUDINESCO, 2003, p. 40)

Também criaram o "Bureau de Pesquisas Surrealistas" ou "Central Surrealista" para o qual convidavam todos aqueles que "têm alguma coisa a dizer, a confessar, a criar e que, apanhados nas malhas da vida monotonamente rotineira, não sabem como livrar-se do peso que os sufoca" (NADEAU, 2008, p. 57). As experiências que ali ocorriam engrandeciam a poética surrealista: 
Suspendemos uma mulher ao teto de um quarto vazio, para onde acorrem cada dia, homens inquietos, portadores de grandes segredos. Foi assim que conhecemos Georges Bessière, como um murro. Dedicamonos a uma tarefa, enigmática para nós mesmos, diante de um volume de Fantasma, pregado à parede por garfos. Os visitantes, nascidos em climas distantes ou à nossa porta, contribuem para a construção desta admirável máquina de matar o que existe, para o acabamento do que não existe. No número 15 da rue de Grenelle, abrimos um romanesco albergue para as ideias inclassificáveis e as revoltas incessantes. Toda esperança que ainda existe neste mundo desesperado há de dirigir seus últimos olhares delirantes para nossa pobre tenda: é preciso elaborar uma nova declaração dos direitos do homem. (ARAGON apud NADEAU, 2008, p. 58)

Este campo de experimentação onírica permitia que se ultrapassassem os limites da subjetividade burguesa do início do século XX, integrando novas correntes de sensibilidade e de pensamento não só no âmbito artístico, mas também transbordava seus efeitos para a vida, para um novo modo de o homem relacionar-se consigo mesmo e com o mundo.

Apoiando-se nessas explorações oníricas de Freud, “(...) uma epidemia de sonos se abateu sobre os surrealistas (...). São sete ou oito que vem tão-somente para esses instantes de esquecimentos onde, com as luzes apagadas, falam sem consciência, como afogados ao ar livre" (ARAGON apud NADEAU, 2008, p. 50). Os surrealistas encontraram nos sonhos sua dimensão poética, buscando explorar os mesmos mecanismos regressivos (inversos aos interpretativos) do trabalho dos sonhos para compor suas obras. Ainda segundo Aragon (ibidem, p. 49): “(...) Era o tempo em que, nos reunindo à tarde quais caçadores, fazíamos nosso quadro do dia, a conta dos animais que havíamos inventado, das plantas fantásticas, das imagens abatidas". Assim, para estes artistas do início do século XX, "o inconsciente não é apenas uma dimensão psíquica explorada com maior facilidade pela arte, devido à sua familiaridade com a imagem, mas é a dimensão da existência estética e, portanto, a própria dimensão da arte" (ARGAN, 1999, p. 360). Valendo-se desta dimensão estética do inconsciente, temos como exemplo (de muitas outras obras que poderíamos citar) o quadro Sonho causado pelo voo de uma abelha ao redor de uma romã um segundo antes de acordar, pintado em 1944, por Salvador Dalí.

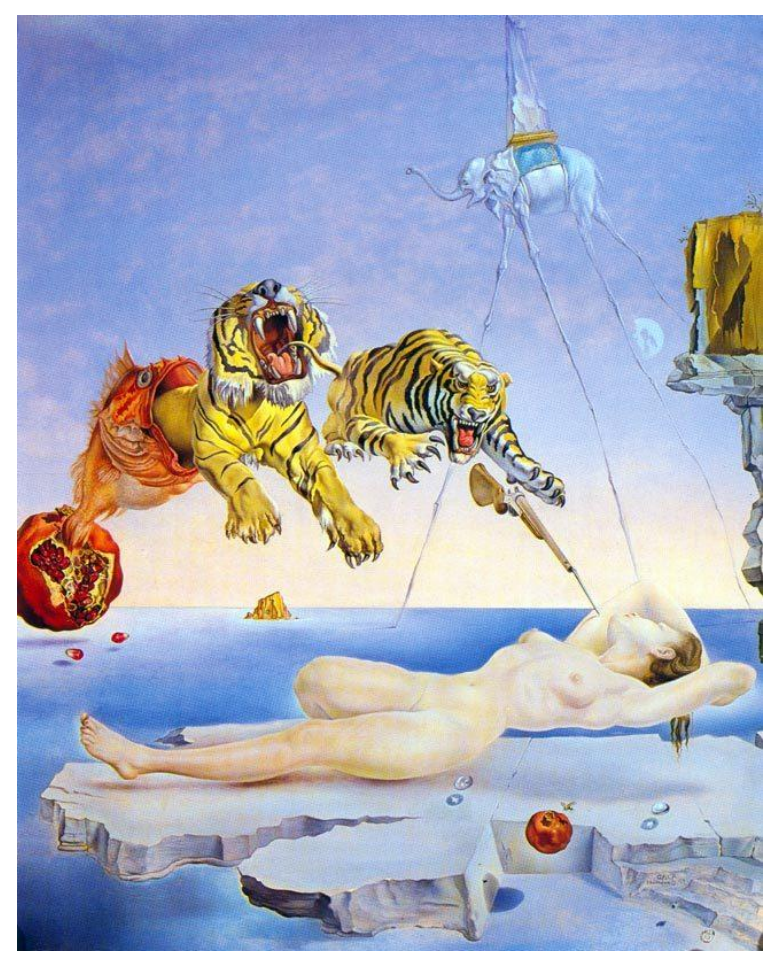

SALVADOR DALÍ

Sonho causado pelo voo de uma abelha ao redor de uma romã um segundo antes de acordar, 1944. 
Não eram apenas as temáticas psicanalíticas que instigavam esses artistas, mas principalmente a maneira de operar do inconsciente. A figuração, o deslocamento, a condensação, a inversão e o caráter múltiplo das formações inconscientes, ou seja, os próprios mecanismos do trabalho do sonho que constituíam o forro ou estrutura sobre as quais as obras surrealistas eram erigidas. Não buscavam um sentido para suas obras - o que seria interpretá-las - mas realizar justamente o inverso: o processo regressivo do trabalho do sonho como recurso de produção artística, como método de construção poética.

Desta maneira, encantados com o universo inconsciente que a descoberta freudiana desvelou e cientes de sua força subversiva, os surrealistas fizeram da Interpretação dos sonhos (1900) de Freud seu principal guia de trabalho poético.

Recebido em: 9 de maio de 2015. Aprovado em: 7 de novembro de 2015.

\section{REFERÊNCIAS}

ADES, D. Dadá e surrealismo. In: STANGOS (org.) Conceitos da Arte Moderna. Rio de Janeiro: Jorge Zahar Editor, 2000.

ARGAN, G. C. Arte moderna. São Paulo: Companhia das Letras, 1999.

BRADLEY, F. Surrealismo. São Paulo: Cosac Naify, 1999.

DEMPSEY, A. Estilos, escolas e movimentos: guia enciclopédico da arte moderna. São Paulo: Cosac Naify, 2003.

FRAYZE-PEREIRA. Grete e Freud: fotografias e psicanálise, sonho e interpretação. In: Os sonhos de Grete Stern: fotomontagens. São Paulo: Imprensa Oficial, 2009.

FREUD, S. A interpretação dos sonhos (1900). Rio de Janeiro: Imago, 1996. (Obras completas, 4).

7). Fragmento da análise de um caso de histeria. Rio de Janeiro: Imago, 1996. (Obras completas,

GANHITO, N.C.P. Distúrbios do sono. São Paulo: Casa do Psicólogo, 2003.

GARCIA-ROZA, L. A. Introdução à metapsicologia freudiana: a interpretação do sonho. V. 2. Rio de Janeiro: Jorge Zahar Editor, 2002.

Freud e o inconsciente. Rio de Janeiro: Jorge Zahar Editor, 2011.

GOMBRICH, E. As teorias estéticas de Sigmund Freud. Percurso, São Paulo, n. 15, p. 5-16, 1995.

LODDI, L. Casa de bricolador(a): cartografias da bricolagem. Dissertação (mestrado em Artes), Universidade Federal de Goiás, Goiânia, 2010.

MICHELI, M. de. As vanguardas artísticas. São Paulo: Martins Fontes, 2004.

NADEAU, M. História do surrealismo. São Paulo: Editora Perspectiva, 2008.

PASSETTI, D. V. Colagem: arte e antropologia. Ponto e vírgula. Revista Eletrônica Semestral do Programa de Estudos de pós-graduandos em Ciências Sociais da PUC-SP, 1o semestre, n. 1, 2007

ROBERT, M. A revolução psicanalítica. São Paulo: Editora Perspectiva, 1991.

ROUDINESCO, E. História da psicanálise na França: a batalha dos 100 anos. V. 2. Rio de Janeiro: Jorge Zahar Editor, 2003.

SUBIRATS, E. Da vanguarda ao pós-moderno. São Paulo: Nobel, 1984.

RIVERA, T. Arte e psicanálise. Rio de Janeiro: Jorge Zahar Ed., 2002.

\section{Paula Carpinetti Aversa}

p_aversa@hotmail.com 